\title{
PENERAPAN METODE CERAMAH VARIASI DAN DISKUSI SERTA MEDIA GAMBAR UNTUK MENINGKATKAN KEMAMPUAN SISWA PADA MATA PELAJARAN PKn KELAS V DI SDN 3 GROBOGAN
}

\author{
Karmini \\ Kepala SD Negeri 3 Grobogan Jawa Tengah \\ Surel : karminikepsek@gmail.com
}

\begin{abstract}
Variation Application Methods Lecture and Discussion And Media Images To Enhance Students Ability Civics Lesson In Class V at SDN 3 Grobogan. The purpose of this class action research is to investigate the application of a lecture and discussion variations and the use of images in the media increase the ability of students in the Competency Standards Civics Understand Freedom to Organize Class V. The subjects in this study were students of class V SD Negeri 3 Ngambakrejo. Implemented in the second semester of academic year 2015/2016. The results showed increased mastery learning which students completed the first cycle were 13 students with an average value of 73.10. Cycle II students who completed as many as 15 students with an average value of 78.94 class.
\end{abstract}

Keyword : Learning Results Civics, Method of Variation Lecture, Discussion

\begin{abstract}
Abstrak : Penerapan Metode Ceramah Variasi Dan Diskusi Serta Media Gambar Untuk Meningkatkan Kemampuan Siswa Pada Mata Pelajaran PKn Kelas V Di SDN 3 Grobogan. Tujuan dari penelitian tindakan kelas ini adalah untuk mengetahui penerapan metode ceramah variasi dan diskusi serta penggunaan media gambar dalam meningkatkan kemampuan siswa pada mata pelajaran PKn Standar Kompetensi Memahami Kebebasan Berorganisasi Kelas V. Subyek dalam penelitian ini adalah siswa kelas V SD Negeri 3 Ngambakrejo. Dilaksanakan pada semester genap tahun pelajaran 2015/2016. Hasil penelitian menunjukkan ketuntasan belajar meningkat yaitu siklus I siswa tuntas sebanyak 13 siswa dengan nilai rata-rata 73,10 . Siklus II siswa yang tuntas sebanyak 15 siswa dengan nilai ratarata kelas 78,94.
\end{abstract}

\section{Kata Kunci : Hasil Belajar PKn, Metode Ceramah Variasi, Diskusi}

\section{PENDAHULUAN}

Sebagai bukti dari keberhasilan proses pembelajaran adalah jika siswa menguasai materi pembelajaran. Penguasaan materi ini ditentukan pada nilai-nilai dari setiap tahap pembelajaran. Tujuan pembelajaran ini ditentukan oleh banyak faktor diantaranya adalah penggunaan media pembelajaran. Dalam pembelajaran kedua digunakan untuk membantu siswa mempelajari obyek, suara, proses, peristiwa atau lingkungan yang sulit dihadirkan di dalam kelas. Dengan media, pembelajaran akan terasa lebih hidup/aktif, menyenangkan dan bermakna.

Efektifitas penggunaan
media pembelajaran tergantung
dari kemampuan guru dan
ketepatan dalam memilihnya.
Penggunaan media pembelajaran
yang tepat dan relevan dengan
materi yang akan diajarkan akan
lebih meningkat proses belajar dan basil
belajar siswa.

Pembelajaran yang berhasil akan ditunjukkan dengan dikuasainya materi oleh siswa yang dapat dilihat niiai yang diperoleh siswa. Demikian halnya yang terjadl di kelas yang peneliti alami di kelas V Semester 2 tahun 2015/2016. Dari hasil 
Jurnal Guru Kita (JGK). Vol 1 (2) Maret 2017, hlm. 1-9

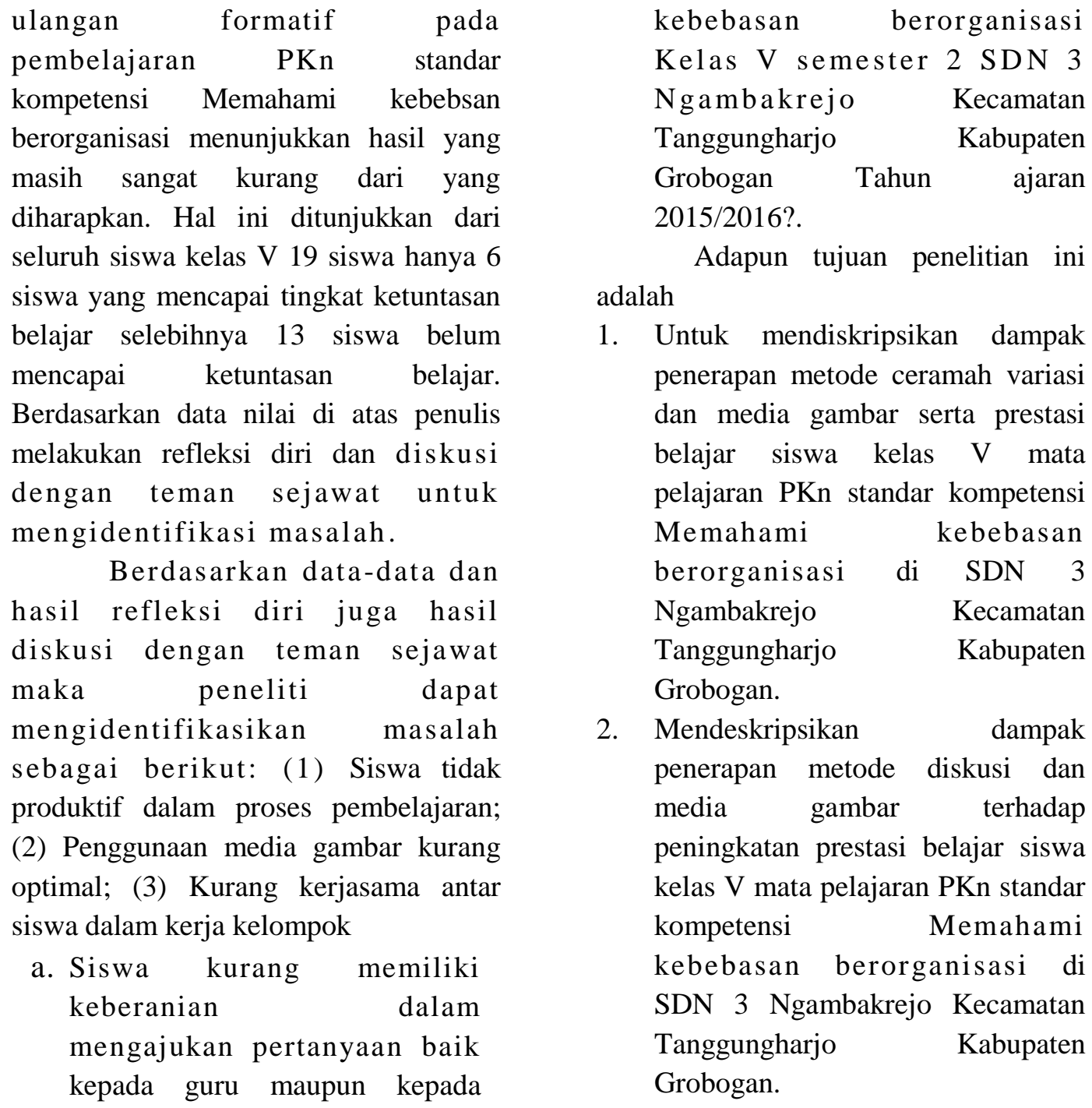
siswa teman sebayanya

$$
\text { Agar dapat mencapai }
$$
tujuan yang telah ditetapkan maka peneliti merencanakan untuk melakukan Penelitian Tindakan Kelas (PTK) untuk meningkatkan hasil belajar yang diharapkan.

Berdasarkan identifikasi masalah di atas maka dapat dirumuskan masalah sebagai berikut:

1. Bagaimana penerapan metode ceramah, variasi dan diskusi serta media gambar untuk meningkatkan prestasi belajar siswa pada mata pelajaran PKn standar kompetensi Memahami

\section{METODE}

Perbaikan pembelaiaran ini dilaksanakan di kelas $\mathrm{V}$ SDN 3 Ngambakrejo Kecamatan Tanggungharjo Kabupaten Grobogan. Pelaksanaannya dimulai pada tanggal 29 Januari sampai dengan 5 Pebruari 2016 dengan mata pelajaran PKn materi Kebebasan Berorganisasi.

Adapun jadwal pelaksanaannya sebagai berikut:

1. Siklus I dilaksanakan tanggal 29 Januari 2016

2. Siklus II dilaksanakan tanggal 5 Februari 2016

Pelaksanakan perbaikan 
pembelajaran ini dibantu oleh teman sejawat yang bernama Sugito yang telah melakukan pengamatan jalannya proses pembcla $a_{j}$ aran. Kepala Sekolah SDN 3 Ngambakrejo yang telah memberikan ijin atas pelaksanaan perbaikan dan dukungan sepenuhnya sampai selesainya penelitian ini.

$$
\text { Tahap rencana ini }
$$

peneliti lakukan setelah mengidentifikasi masalah yang timbul bersama teman sejawat. Sebelum melaksanakan perbaikan pembelajaran peneliti berdiskusi dengan teman sejawat dan berkonsultasi dengan supervisor untuk mengatasi dan mengungkap permasalahan yang ditemukan. Kemudian menyusun rancangan perbaikan pembelajaran mata pelajaran PKn dengan standar kompetensi memahami Kebebasan berorganisasi di kelas V Semester 2 dengan tujuan agar pemahaman siswa lebih meningkat.

Adapun langkah-langkah perbaikan pembelajaran siklus I adalah sebagai berikut :

- Merancang pembelajaran yang memfokuskan pada penggunaan media gambar struktur organisasi dan tata tertib organisasi

- Menyiapkan media yang diperlukan yaitu gambar struktur organisasi dan tata tertib organisasi

- Menyiapkan lembar observasi

- Menyusun evaluasi.

$$
\text { Pelaksanaan perbaikan }
$$

pembelajaran siklus II peneliti merencanakannya hampir sama dengan pelaksanaan pembelajaran siklus hanya ada beberapa hal yang perlu dilakukan penanganan secara lebih matang lagi.
Pelaksanaan

perbaikan pembelajaran siklus II ini peneliti memfokuskan pada penggunaan media gambar struktur organisasi dalam diskusi kelompok.

Adapun prosedur pelaksanaannya sebagai berikut

- Merancang perbaikan pembelajaran

- Menyiapkan media yang diibutuhhan berupa gambar struktur organisasi

- Menyiapkan lembar observasi

- Menyusun tes formatif

- Menyiapkan lembar analisa

\section{PEMBAHASAN}

Pada tahap perencanaan peneliti merancang rencana perbaikan pembelajaran untuk siklus I. menyiapkan alat bantu pembelajaran yang sesuai dengan standar kompetensi memahami memahami kebebasan berorganisasi yaitu gambar struktur organisasi dan Instrument pelengkap yang dibutuhkan antara lain lembar observasi, lembar soal tes formatif dan lembar analisa perillaian.

Semua rencana sudah peneliti persiapkan dan dapat terlaksana dengan balk. Adapun data-data selengkapnya terlampir.

Pelaksanaan perbaikan pembelajaran siklus I pada tanggal 29 Januari 2016 dengan mata pelaJaran PKn standar kompetensi memahami kebebasan berorganisasi. Prosedur pelaksanaannya melalui tahaptahap sesuai dengan rencana pembelajaran pada umumnya.

Dimulai dari kegiatan awal, kegiatan inti, dan kegiatan akhir yang ditandai dengan evaluasi pembelajaran dengan tes formatif. Hasilnya dianalisa 
untuk mengetahui tingkat keberhasilan proses pembelajaran.

Dari hasil analisa tes formatif siklus I menunjukkan hasil yang kurang memuaskan karena nilai terendah yang diperoleh siswa dan nilai tertinggi 100. dari 19 siswa yang mencapai nilai ketuntasan hanya 16 siswa dan 3 siswa belum dapat mendapat nilai ketuntasan belajar 7,5 Nilai-rata- rata kelas mencapai $78,94 \%$

Berdasarkan perolehan nilai siklus I yang belum mencapai ketuntasan belajar maka pcnulis merencanakan perbaikan pembelajaran pada siklus II. Berikut ini adalah data nilai sebelum perbaikan dan perbaikan pembelajaran siklus I.

Tabel Dan Grafik Hasil Perolehan Nilai Tes Formatif Sebelum Perbaikan Dan Perbaikan Siklus I

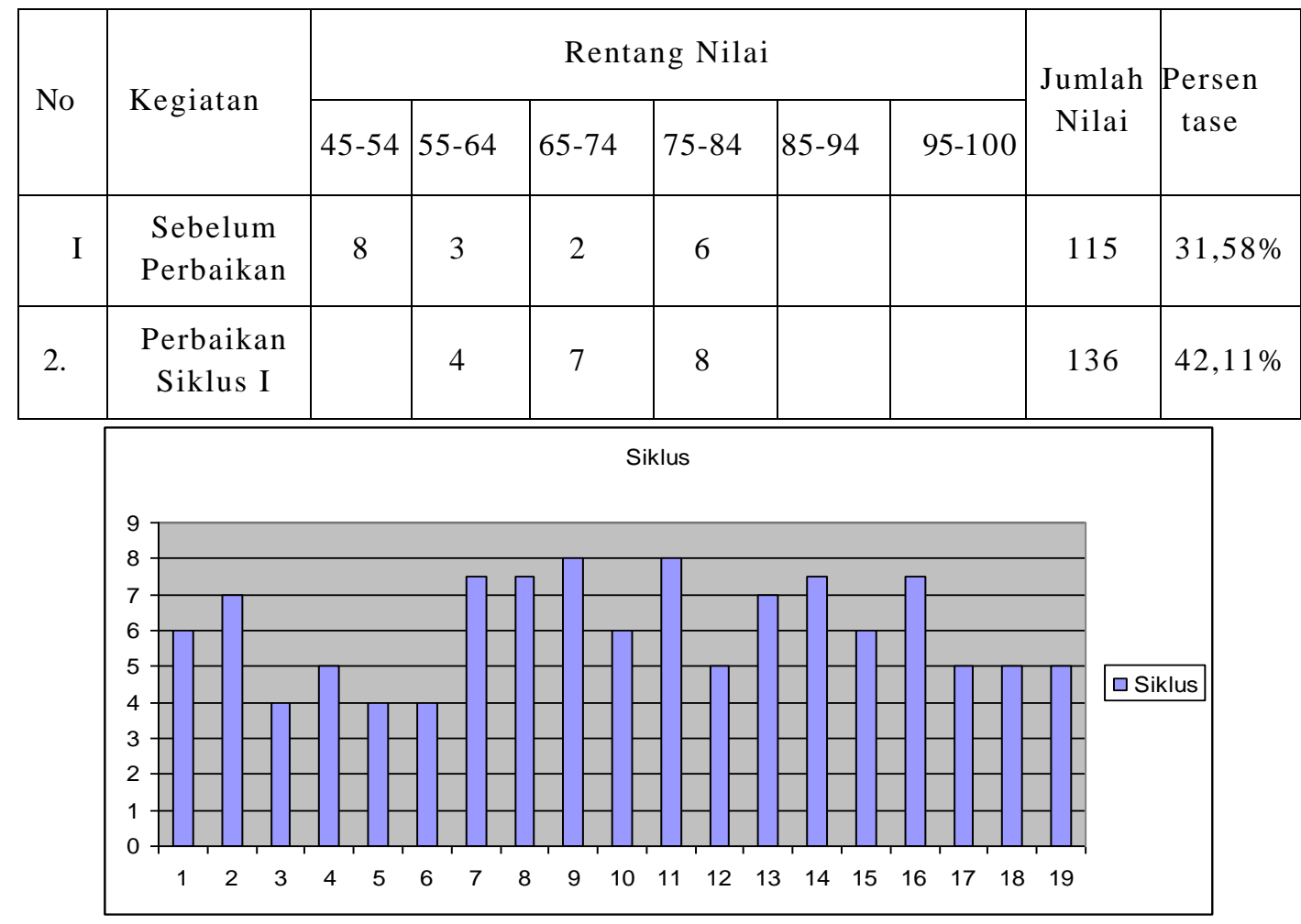

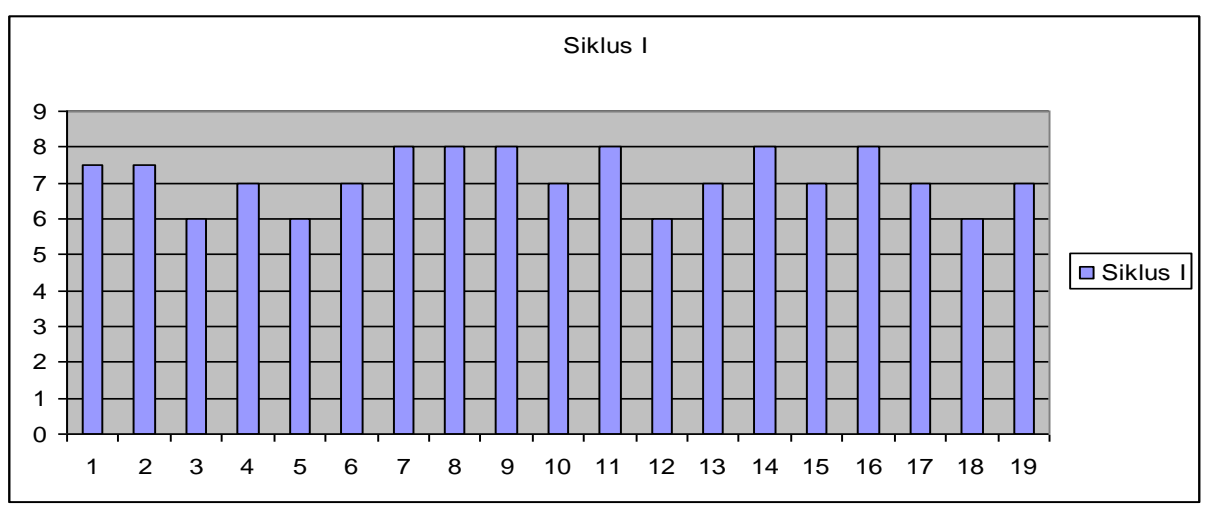


Observer telah melakukan pengamatan dan mengumpulkan data tentang jalannya proses pcmbelajaran baik terhadap guru maupun terhadap siswa. Dari hasil pengamatan terhada guru diperoleh data bahwa guru sudah menggunakan media

$\begin{array}{lrr}\text { dalam pembelajaran } & \text { tetapi } \\ \text { penggunaan gambar } & \text { struktur } \\ \text { organisasi dan } & \text { belum } & \text { optimal } \\ \text { pemilihan metode masih } & \text { kurang }\end{array}$ bervariasi jadi jalannya pernbelajaran monoton. Guru tidak ikut aktif dalam diskusi kelompok sehingga banyak siswa yang tidak antusias melakukan diskusi kelompok.

Dari hasil pengamatan terhadap siswa diperoleh data bahwa dalam diskusi kelompok siswa kurang aktif. Siswa terlihat raga-ragu dalam menjawab / mengerjakan tugas. Hal ini disebabkan instruksi yang diberikan kurang dipahami siswa. Data hasil pengamatan selengkapnya ada pada lampiran.

Setelah melaksanakan perbaikan pembelajaran siklus I dapat diidentifikasi masalah-masalah sebagai berikut :

a. Guru belum menjelaskan penggunaan gambar struktur organisasi dan secara efektif

b. Penggunaan metode dalam pembelajaran kurang bervariasi

c. Antusias bclajar siswa masih rendah karena guru kurang memberikan motivasi

Dari data yang diperoleh di atas dapat disimpulkan bahwa proses pcmbelaJaran pada siklus I masih menunjukkan tingkat pemahamaan siswa terhadap materi ajar yang rendah. Nilai yang diperoleh dari hasil tes formatif dari 19 siswa baru 8 siswa yang mencapai nilai ketuntasan belaiar dan 11 siswa belum dapat mencapai nilai ketuntasan belajar yaitu 7,5. Ketidakberhasilan proses perbaikan pembelajaran siklus disebabkan oleh :

a. Penjelasan guru terhadap materi kurang dipahami siswa terutama dalam mempelajari gambar struktur organisasi.

b. Siswa masih ragu-ragu dalam menjawah soal karena pemahaman terhadap materi masih kurang

c. Guru ticlak aktif dalam pembelajaran / diskusi kelompok sehingga antusias belajar siswa kurang

Perencanaan perbaikan untuk siklus II peneliti merancang lebih matang dan langka dengan harapan tujuan, pembelajaran akan tercapai. Kelemahan dan kekurangan yang telah teridentifikasi dari hasil refleksi dan diskusi dengan teman sejawat pada siklus I akan peneliti pecahkan pada proses perbaikan pembelajaran siklus II. Media yang dipergunakan lebih efektif penggunaannya. Instrumen yang dipersiapkan adalah lembar observasi, lembar kerja siswa, lembar soal, lembar analisa. Data lembar-lembar instrumen ada pada lampiran.

Pelaksanaan perbaikan pembelajaran siklus II dilaksanakan pada tanggal 5 Februari 2016 dengan standar kompetensi memahami kebebasan berorganisasi. Prosedur pelaksanaannya melalui tahaptahap yang telah direncakan. 
Pembelajaran dimulai dengan kegiatan awal, kegiatan inti dan kegiatan akhir. Penggunaan media gambar gambar struktur organisasi lebih diefektifkan. Mulai dari mempelajari garis, warna dan kedudukan dalam gambar struktur organisasi dan semua dijelaskan secara rinci dan jelas agar siswa mernahaminya. Keefektifan diskusi kelompok dipantau oleh guru dalam kerja kelompok sehingga tidak ada siswa yang tidak ikut partisipasi dalam diskusi kelompok. Dari hasil tes formatif siklus II menunjukkan peningkatan baik dalam proses maupun dalam hasil belajar. Hal ini dapat dilihat dari nilai yang dicapai oleh siswa. Dari 19 siswa ada 15 siswa yang dapat mencapai nilai ketuntasan belajar atau taraf serapnya mencapai $78,94 \%$ dengan nilai rata-rata kelas mencapai 7,89 . Pada perbaikan pembelajaran siklus II ternyata merupakan pembelajaran yang cukup ideal mcmenuhi syarat-syarat proses pembelajaran yang diperlukan seperti : menetapkan metode yang tepat, menggunakan alat / media pembelajaran secara efektif schingga sangat membantu siswa dalam menyerap informasi yang disampaikan oleh guru dalam hal ini adalah materi pelajaran. Peningkatan nilai hasil evaluasi pembelajaran PKn dapat digambarkan dalam tabel dan diagram batang di bawah ini mulai dari perbaikan-perbaikan pembelajaran siklus I dan II, sebagai berikut :

Tabel Hasil Perolehan Nilai Tes Formatif Sebelum Perbaikan, Perbaikan Siklus I Dan Siklus Ii

\begin{tabular}{|c|c|c|c|c|c|c|c|c|c|}
\hline \multirow{2}{*}{ No } & \multirow{2}{*}{ Kegiatan } & \multicolumn{6}{|c|}{ Rentang Nilai } & \multirow{2}{*}{$\begin{array}{c}\text { Jumlah } \\
\text { Nilai }\end{array}$} & \multirow{2}{*}{$\begin{array}{c}\text { Persen } \\
\text { tase }\end{array}$} \\
\hline & & $45-54$ & $55-64$ & $65-74$ & $75-84$ & $85-94$ & $95-100$ & & \\
\hline 1. & $\begin{array}{l}\text { Sebelum } \\
\text { Perbaikan }\end{array}$ & 8 & 3 & 2 & 6 & & & 115 & $31,58 \%$ \\
\hline 2. & $\begin{array}{c}\text { Perbaikan } \\
\text { Siklus I }\end{array}$ & & 4 & 7 & 8 & & & 136 & $42,11 \%$ \\
\hline 3. & $\begin{array}{c}\text { Perbaikan } \\
\text { Siklus II }\end{array}$ & & & 4 & 13 & 2 & & 150 & $78,94 \%$ \\
\hline
\end{tabular}


Grafik Perolehan Nilai Tes Formatif Sebelum Perbaikan, Pfrbaikan Siklus I Dan Siklus Ii

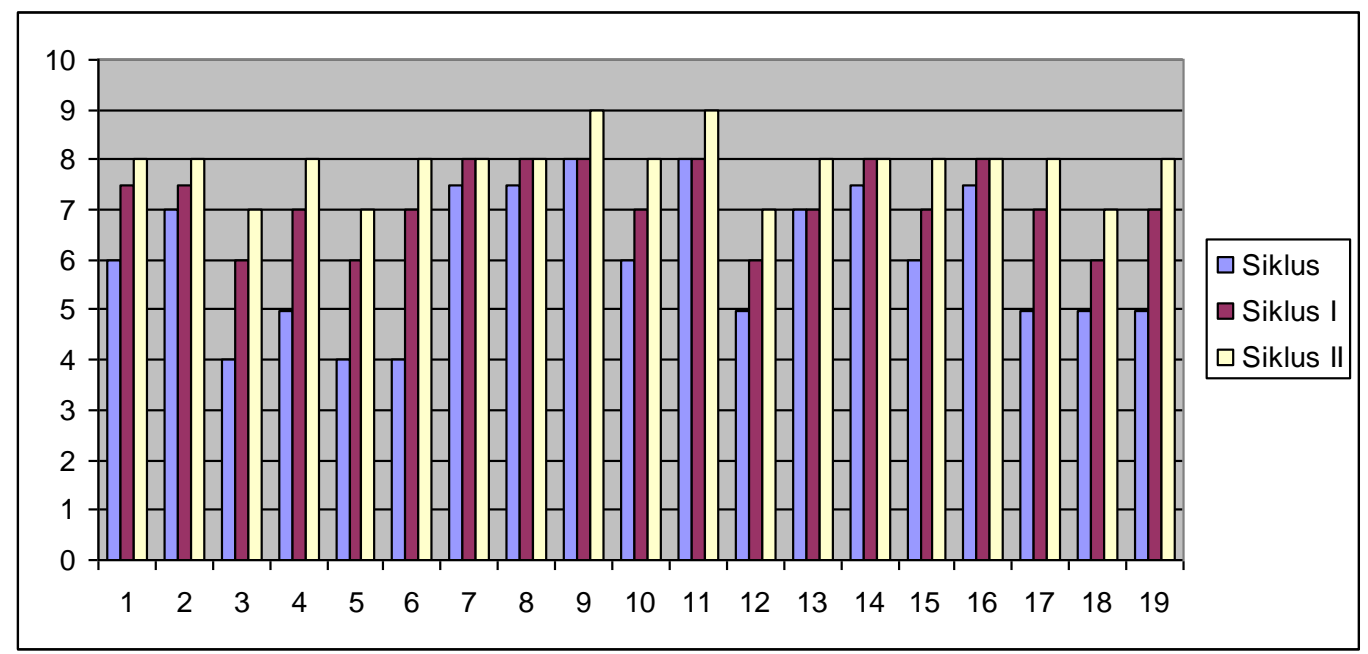

RENTANG NILAI

Pada tahap pengamatan pembelajaran siklus II observer memperoleh data bahwa dalam pembelajaran soal sudah menggunakan media dan menjelaskan penggunaannya secara jelas. Metode yang dipilih dan digunakan dalam pembelajaran sangat tepat dan divariasi antara metode ceramah, tanya jawab, demonstrasi, diskusi kelompok dan tugas.

Hasil pengamatan terhadap kegiatan siswa observer menemukan karena mendapat bimbingan dari guru. Dalam menggunakan gambar bencana alam dan siswa tidak ragu-ragu karena penjelasan dari guru sudah dipahami. Data-data dari hasil pengamatan dan pengumpulan data dapat dilihat pada bagian lampiran.

Peneliti melakukan renungan atas kegagalan dan keberhasilan selama proses pembelajaran. Teryata keberhasilan suatu proses pembelajaran bergantung pada persiapan. pelaksanaan dan evaluasi yang dilakukan oleh guru.

Khusus pada pelaksanaan perbaikan pembelajaran mata pelajaran PKn dengan standar kompetensi Memahami kebebasan berorganisasi di kelas V Semester 2 SD Negeri 3 Ngambakrejo Kecamatan Tanggungharjo Kabupaten Grobogan diperlukan beberapa hal yang harus dilakukan oleh guru yaitu

a. Penggunaan media berupa gambar struktur organisasi dan secara benar dan efektif dengan petunjuk yang jelas

b. Pemilihan metode yang tepat dan bervariasi yaitu diskusi kelompok dengan variasi metode ceramah, tanya jawab dan tugas

c. Peran serta guru dalam diskusi kelompok artinya guru harus

d. memberikan bimbingan kelompok ketika siswa melaksanakan diskusi 
Dengan kiat-kiat yang dipilih guru di atas terbukti sangat efektif meningkatkan pemahaman siswa terhadap mata pembelajaran.

Berdasarkan hasil yang diperoleh dari sebelum perbaikan, perbaikan siklus I dan II terbukti bahwa pembelajaran memerlukan kompetensi yang tinggi dari seorang guru. Banyak faktor yang mempengaruhi kegagalan dan keberhasilan suatu pembelajaran.

Dari beberapa kajian teori mengenai pembelajaran, yang paling menentukan keberhasilan pembelajaran adalah kemampuan guru dalam mengelola pembelajaran. Pengelolaan pembelajaran itu meliputi cara memilih strategi, metode dan media yang digunakan dalam pembelajaran.

Pembelajaran pada siklus I masih banyak hal-hal yang belum dilaksanakan oleh guru secara optimal seperti penggunaan metode dan media sehingga tingkat pemahaman siswa terhadap materi ajar masih rendah.

Pelaksanaan diskusi kelompok masih kurang menarik minat siswa. Hal ini disebabkan kurang jelasnya penjelasan/ instruksi guru kepada siswa dalam menyelesaikan tugas sehingga siswa tampak ragu-ragu dalam menyelesaikan tugas.

Hasil analisa penilaian menunjukkan masih rendahnya pemahaman-pemahaman siswa terhadap materi pelajaran. Dari 19 siswa yang mendapat nilai tuntas baru 13 siswa dan 7 siswa belum mencapai nilai tuntas. Nilai rata-rata kelas 73,10. Dengan demikian peneliti merencakan perbaikan pembelajaran siklus II.

Pada pelaksanaan perbaikan pembelajaran siklus II peneliti merancang pembelajaran dengan persiapan yang lebih matang. Media yang akan digunakan berupa gambar struktur organisasi dan dipersiapkan untuk tiap kelompok kerja siswa.

Hasil analisa penilaian menunjukkan hasil yang lebih baik dari pada perbaikan pembelajaran $^{\mathrm{p}}$, siklus I. Keberhasilan pembelajaran ini disebabkan karena dalam proses pembelajaran guru menggunakan media secara efektif disertai penjelasan penggunaan alat dengan jelas. Pemilihan metode pemberian tugas dan diskusi kelompok sangat tepat.

$$
\text { Karena dengan tugas }
$$
yang dirancang dengan jelas, setiap kelompok menghadapi gambar struktur organisasi dan maka semua siswa akan aktif dalam belajar. Keaktifan siswa dalam mengerjakan tugas kelompok akan meningkatkan pemahaman.

$$
\text { Dengan demikian seperti }
$$
yang dikemukakan pada kajian teori bahwa pembelajaran akan menyenangkan dan bermakna apabila dalam prosesnya guru trampil dalam memilih dan menentukan metode dan media pembelajaran yang disesuaikan dengan materi ajar.

Sebagai bukti r bahwa
pembelajaran itu berhasil
adalah adanya hasil evaluasi yang
mencapai nilai ketuntasan belajar yang
telah ditetapkan. Pada pembelajaran
PKn ini siswa yang tuntas ada 15 dari 19
siswa. Ada 4 siswa yang tidak dapat
mencapai nilai tuntas. Hal ini
disebabkan karena faktor
kelambanan belajar. Nilai rata-rata
kelas mencapai 78,94. Ini terbukti
bahwa hipotesa dugaan yang peneliti
tetapkan dapat tercapai.




\section{KESIMPULAN}

$\begin{array}{crr}\text { Dari hasil perbaikan } \\ \text { pembelajaran } & \text { yang } & \text { sudah }\end{array}$ dilaksanakan dalam dua siklus dapat diambil kesimpulan bahwa penerapan metode ceramah variasi dan diskusi serta media gambar untuk meningkatkan prestasi belajar siswa pada mata pelajaran PKn standar kompetensi Memahami kebebasan berorganisasi Kelas V di SDN 3 Ngambakrejo Kecamatan Tanggungharjo Kabupaten Grobogan.

Dalam melaksanakan pembelajaran seorang guru harus memperhatikan hal-hal sebagai berikut :

a. Memilih dan menggunakan media pembelajaran yang tepat dan kongkrit seperti penggunaan gambar struktur organisasi. Dalam penggunaannya guru harus menjelaskan cara-cara yang efektif.

b. Menentukan metode yang tepat sesuai dengan materi ajar seperti diskusi kelompok divariasi dengan metode yang lain yang sesuai. Dalam menentukan anggota kelompok guru harus jeli dan kreatif agar persebarannya merata. Tugastugas yang diberikan harus dengan petunjuk yang jelas.

c. Keaktifan guru dan siswa yang tinggi akan menentukan keberhasilan pembelajaran

Dengan kelebihan-kelebihan penggunaan media gambar struktur organisasi maka guru akan lebih kreatif lagi dalam menggunakan media ini. Juga media yang lain yang ada di sekitar kita hendaknya digunakan dan dimanfaatkan sebcsar-besamya untuk proses pembelajaran. Penggunaan gambar struktur organisasi akan lebih memudahkan guru dalam menanamkan konsep-konsep tentang kebebasan berorganisasi.

Penggunaan media gambar struktur organisasi ini dapat dijadikan bahan diskusi dalam Kegiaian Kelompok Guru (KKG) mengenai strategi, cara dan manfaatnya sehingga proses pernbelajaran di kelas akan lebih bergairah

\section{DAFTAR RUJUKAN}

Andayani dkk, 2007 : 28, Pemantapan Kemampuan Profesional. Universitas Terbuka. Jakarta.

Tim Pengembang PGSD. 1996/1998, Strategi Belajar Mengajar Il. Dirjen Dikti Departemen Pendidikan dan Kebudayaan. Jakarta

Wardani I.G.A.K, Wihardit . K, Nasoetion N 2003, Penelitian Tindakan Kelas. Universitas Terbuka. Jakarta.

Winataputra dkk. 2002, Materi dan Pembelajaran Pendidikan Kewarganegaraan SD. Universitas Terbuka. Jakarta 